\title{
Heavy Mineral Characteristics and Their Implication for Provenance of the Middle to Upper Triassic on the Northwest Margin of Junggar Basin, North China
}

\author{
Miao $\mathrm{He}^{1}$, Liwei Zhang ${ }^{3}$, Jianxin $\mathrm{Yao}^{2}$, Shuai $\mathrm{Li}^{1}$ \& $\mathrm{Qi} \mathrm{Li}^{1}$ \\ ${ }^{1}$ Research Institute, Shanghai Branch of CNOOC Ltd., Shanghai, China \\ ${ }^{2}$ Geology Institute, Chinese Academy of Geological Sciences, Beijing, China \\ ${ }^{3}$ Institute of Resources \& Environment, Henan Polytechnic University, Jiaozuo, Henan 454000, China \\ Correspondence: Miao He, Research Institute, Shanghai Branch of CNOOC Ltd., Shanghai, 200335, China. \\ E-mail: hemiao3@cnooc.com.cn
}

Received: February 27, 2017

Accepted: March 14, 2017

Online Published: May 14, 2017

doi:10.5539/esr.v6n2p65

URL: https://doi.org/10.5539/esr.v6n2p65

This paper is supported by the "Nonmarine trace fossils response to the end-Permian mass extinction event- $A$ case study of Lower Triassic in Western Henan Province(No. U1204404)”NNational Natural Science Foundation of China.

\begin{abstract}
Heavy minerals are extremely sensitive indicators of provenance. Applying the methods of heavy mineral combination analysis, content distribution analysis, SPSS statistical component analysis, and correlation analysis, 18 heavy minerals are identified in the northwestern margin of the Junggar Basin (NW Junggar). According to the analysis of the heavy mineral characteristics and coefficients, 4 heavy mineral combinations are developed in the study area: Zircon-tourmaline-monazite-apatite-anatase, rutile-ilmenite-leucoxene-apatite-galenite, hematite-limonite-pyrite, and magnetite-epidote-hornblende. Previous results predicted that source rocks consist of intermediate-acidic magmatite, sedimentary rocks and metamorphic rocks, and intermediate-acidic magmatite is considered to be the main source rock. Furthermore, combined with the geological background of NW Junggar, Qier-Halaalat Mountain, which belongs to the Zaire Mountain front, is shown to be the provenance of the study area. The main sources of sediments are flesh-red granite, grey and greyish-green andesite, andesitic-porphyrite, grey and grayish-black tuff, siltstone, and sandstone of the Lower Carboniferous Tailegula Formation. Additionally, because of the high content of the angular-subangular and subangular-subrounded heavy mineral grains, these heavy minerals are both from near and distal provenance, with most being near-provenance deposits. During the process of provenance propulsion on the margin of the basin, clastics are mixed together and affected by regional dynamic metamorphism, which is probably the main reason for the existence of the metamorphic component.
\end{abstract}

Keywords: Junggar, Triassic, Carboniferous, provenance, heavy mineral, component analysis, component analysis, correlation analysis

\section{Introduction}

A series of methods exist for the analysis of the provenance of rocks, such as variation of seismic waves, glutinite body thickness statistics, ZTR index distribution, detrital composition observation, geochemistry analysis, fission-track and identification of pollen types (Yalcin, 2008; Yang et al., 2009; Carroll et al., 2010; Zheng et al., 2013; Xu et al., 2013; Zhang et al., 2014; Kang et al., 2014; Zhao et al., 2014). Among these methods, the method involving the use of a heavy mineral combination and its content variation of clastic rocks to both trace the provenance and obtain the source rock information has been widely applied (Cao et al., 2013; Yang et al., 2013). Recently, previous researchers performed a number of research studies on the Mesozoic terrigenous clastic sediments in the Junggar Basin. Most of these studies focused on the analysis of the constitution of the provenance system of the north, east and south part of the basin (Xiao et al., 2011; Yang et al., 2013; Lin et al., 2013), primarily using the methods of clastic compositions (Quartz, feldspar, detrital), ZTR 
index, stability index, planar distribution of heavy mineral combination and REE distribution pattern, and so on to determine the type of source rock and its provenance. Meanwhile, a few results were produced via the research of the Jurassic ancient current and rock debris, among others on the northwestern margin of Junggar Basin (NW Junggar). It is believed that the provenance area is the Zaire Mountain, and the current flew mainly from northwest to southeast, considering that the source rock contains metamorphic rocks, basic-neutral magmatite, acid magmatite and reconstructed sedimentary rock. In this research, 5 well-developed outcrop profiles were selected during the field trip, and 20 glutinite and sandstones, on separate positions of these profiles, were taken as samples. Combining the analysis results of these samples with the heavy mineral characteristics and the multivariate statistical method, the relationships and their combination types of the Middle-Upper Triassic heavy minerals on NW Junggar were systematically analyzed. The combination of source rock and its provenance area are described as well, providing beneficial evidence to the further description of provenance type and its tectonic background.

\section{Geological Background}

Junngar Basin lies among the Kazakhstan plate, the Siberian plate and the Tianshan orogenic belt. The Junngar Basin is a large-scaled Late Paleozoic to Mesozoic and Cenozoic superimposed basin and is surrounded by Paleozoic folded mountains. The study area is approximately $2-10 \mathrm{~km}$ to the north side of Karamay City in Xinjiang, North China (Fig. 1). Various up-and-down movements occurred since the Paleozoic, and subduction and collision formed a series of north-east to northwest faults (Choulet et al., 2013), which are also the foreland thrust belts formed from the late stage of the Late Paleozoic to the early stage of the Mesozoic. During the end stage of the Permian, the Carboniferous northwest mountains were uplifted again as the large scale of mountain orogenesis occurred on the Junggar Basin. After that period, the crust transitioned from being active to stable. The mountains were constantly flattened by erosion in the Triassic, and the Junggar Basin is becoming a compressed depression basin (Li et al., 2007). The nearby northwest mountains became a high uplifted area compared to the study area.

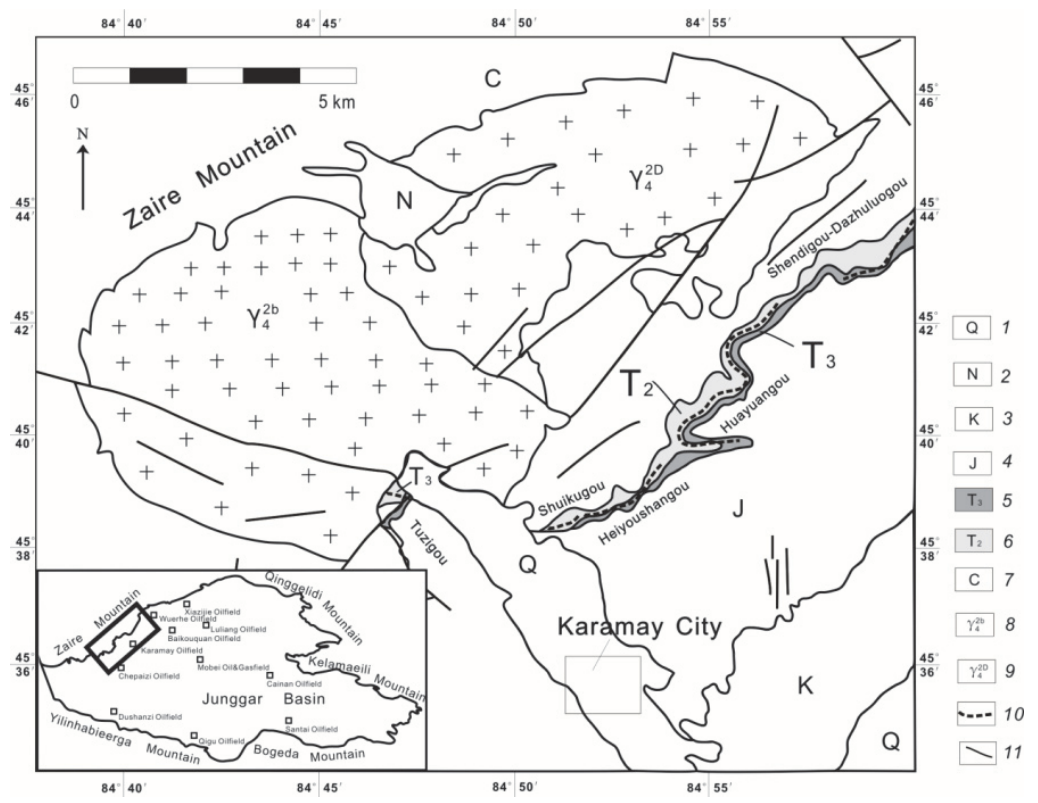

Figure 1. Outcrop distribution of Triassic on NW Junggar

1. Quaternary Neogene, 2. Cretaceous, 3. Jurassic, 4. Carboniferous, 5. Upper Triassic, 6. Middle Triassic, 7. Potassic/Hornblende/Biotite granite, 8. Pragiogranite, 9. Granodiorite, 10. Outcrop profile, 11. Fault

In the study area, the Lower Karamay Formation, the Upper Karamay Formation and the Baijiantan Formation are all concluded in the Triassic, mainly depositing conglomerate, sandstone and mudstone from bottom to top (Fig. 2). The grain content of these sedimentary rocks is complicated. The Middle to Upper Triassic strata misses the Lower Triassic on the outcrops, and the Carboniferous below are on unconformity contact (Fig. 2). The northwestern part of the study area is next to the Halaalat Mountain area, which belongs to the Front Zaire Mountain. The Carboniferous Tailegula Formation $(\mathrm{C} 1 \mathrm{t})$ volcaniclastic rocks are widely deposited. The Late Hercynian intrusive rock systems, such as potash granite-hornblende granite-biotite granite and plagioclase 
granite-granodiorite-granite, are well-developed. The NW Junggar magmatite are extensively developed, and they are distributed in a sheet-shape. The formation of the magmatite is divided into two periods, the Early Carboniferous (340 320Ma) (Gao et al., 2013) and Late Carboniferous to Early Permian (310 290Ma), and the activity of the second period is stronger. After these two periods, the magmatic activity became substantially weaker. The Early Carboniferous granite was developed in the Zhaerma, Sawuer, Taerbahatai and Sentasi districts, containing monzodiorite, granodiorite, granodiorite, two long granites and K-feldspar granite. The intrusive species were various from the Late Carboniferous to the Early Permian, and they were mainly K-feldspar granite, along with a large amount of A-type granite that developed in this period (Chen et al., 2004; Geng et al.,2009; Chen et al., 2010).

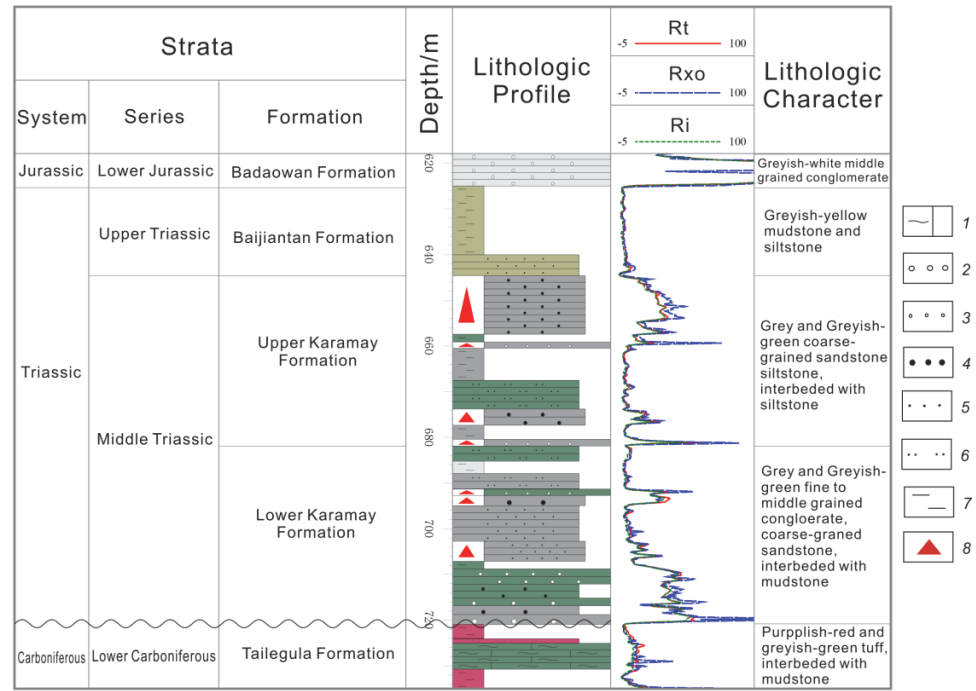

Figure 2. Geological comprehensive histogram of well 8-2A in Karamay

1. Tuff, 2.Middle-grained conglomerate, 3. Fine-grained conglomerate, 4. Coarse-grained sandstone, 5. Fine-grained conglomerate, 6. Siltstone, 7. Mudstone, 8.Oil-containing

\section{Sample Collection and Identification}

The research strata are the Middle to Upper Triassic on Shendigou-Dazhuluogou, Huayuangou, Heiyoushangou, Shuikugou and Tuzigou (Fig. 1). Twenty glutenite and sandstone samples are used for heavy mineral analysis in the Langfang Regional Geological and Mineral Survey Research Laboratory in Hebei Province, China. The rocks are first crushed into 200 mesh, and then, the heavy minerals are collected after shaking and repeated washing. Subsequently, a microscope is used to identify the minerals, and according to the statistics of the grains, and the percentage of each mineral is obtained. Component analysis and correlation analysis are applied to acquire a comparatively accurate heavy mineral combination by taking advantage of the SPSS software multivariate statistical theory.

\section{Heavy Mineral Analysis}

\subsection{Heavy Mineral Types and Characteristics}

Heavy minerals are sensitive indicators of the provenance changes; therefore, according to the heavy mineral types and combinations that appear in clastic rocks, the provenance and its rock types of sandstones are determined (Svendsen et al., 2002). In this research, 18 heavy minerals are identified in 20 glutenite and sandstone samples from 5 outcrop profiles on the NW Junggar: zircon, tourmaline, rutile, hematite-limonite, magnetite, ilmenite, leucoxene, anatase, garnet, chromite, monazite, pyrite, galena, apatite, allanite, epidote, pyroxene and hornblende (Table 1, Table 2). Among these minerals, zircon is the main mineral, including 2 types; over $95 \%$ of are yellowish-pink zircons, automorphic to hypautomorphic columns to broken columns (Fig. 3a), transparent, with a weak adamantine luster. The grains are well-sorted, angular to subangular-subrounded. One to five percent of the grains are rosy zircons, are cylindrical or grainy, and are transparent to semitransparent, with a frosted glass luster. The grains are well-sorted and in rounded shape. Each iron ore occupies a higher content than the other minerals in total (Table 1). Most grains are hypautomorphic, angular to subangular. Unstable minerals, such as pyrite, are significantly hematited and limonited (Fig. 3b). Tourmaline, which belongs to the associated minerals, appears dark brown because of high $\mathrm{Fe}$ content, has a hypautomorphic 
columnar shape (Fig. 3c) and is transparent, with a glassy luster and high hardness. Some tourmalines are worm-shaped and appear bluish-green when using a crossed polarizer, with vertical lines and horizontal joints (Fig. 3d). Reddy-brown rutiles are mainly hypautomorphic, subrounded grains (Fig. 3e), with a greasy luster and high hardness. Garnets are pink, subangular and transparent, with a glassy luster and high hardness. Furthermore, altered minerals, such as allanite, epidote, and so on, and a large amount of altered mineral debris and iron debris, are included in rock samples; mica are visible sometimes. Light minerals in rocks are mainly angular to subangular quartz as well (Fig. 3f).

Table 1. Heavy mineral classification of Milddle-Upper Triassic, NW Junggar

\begin{tabular}{|c|c|c|c|}
\hline Location & Main mineral & Secondary mineral & Associated mineral \\
\hline $\begin{array}{l}\text { Shendigou- } \\
\text { Dazhuluogou }\end{array}$ & $\begin{array}{l}\text { zircon, hematite-limonite, } \\
\text { ilmenite }\end{array}$ & leucoxene, magnetite & $\begin{array}{l}\text { pyrite, anatase, rutile, chromite, garnet, } \\
\text { galena, anatase, apatite }\end{array}$ \\
\hline Huayuangou & $\begin{array}{l}\text { zircon, pyrite, magnetite, } \\
\text { ilmenite, hematite-limonite }\end{array}$ & epidote, hornblende & galena, tourmaline, anatase \\
\hline Heiyoushangou & $\begin{array}{l}\text { tourmaline, zircon, } \\
\text { ilmenite, garnet, chromite }\end{array}$ & $\begin{array}{l}\text { hematite-limonite, } \\
\text { monazite }\end{array}$ & $\begin{array}{l}\text { pyrite, magnetite, apatite, epidote, } \\
\text { pyroxene }\end{array}$ \\
\hline Shuikugou & hematite-limonite & $\begin{array}{l}\text { galena, pyrite, } \\
\text { magnetite, zircon }\end{array}$ & tourmaline, garnet, pyroxene \\
\hline Tuzigou & zircon, ilmenite, leucoxene & hematite-limonite & $\begin{array}{l}\text { tourmaline, magnetite, pyroxene, } \\
\text { rutile, pyrite, chromite, anatase, galena }\end{array}$ \\
\hline
\end{tabular}
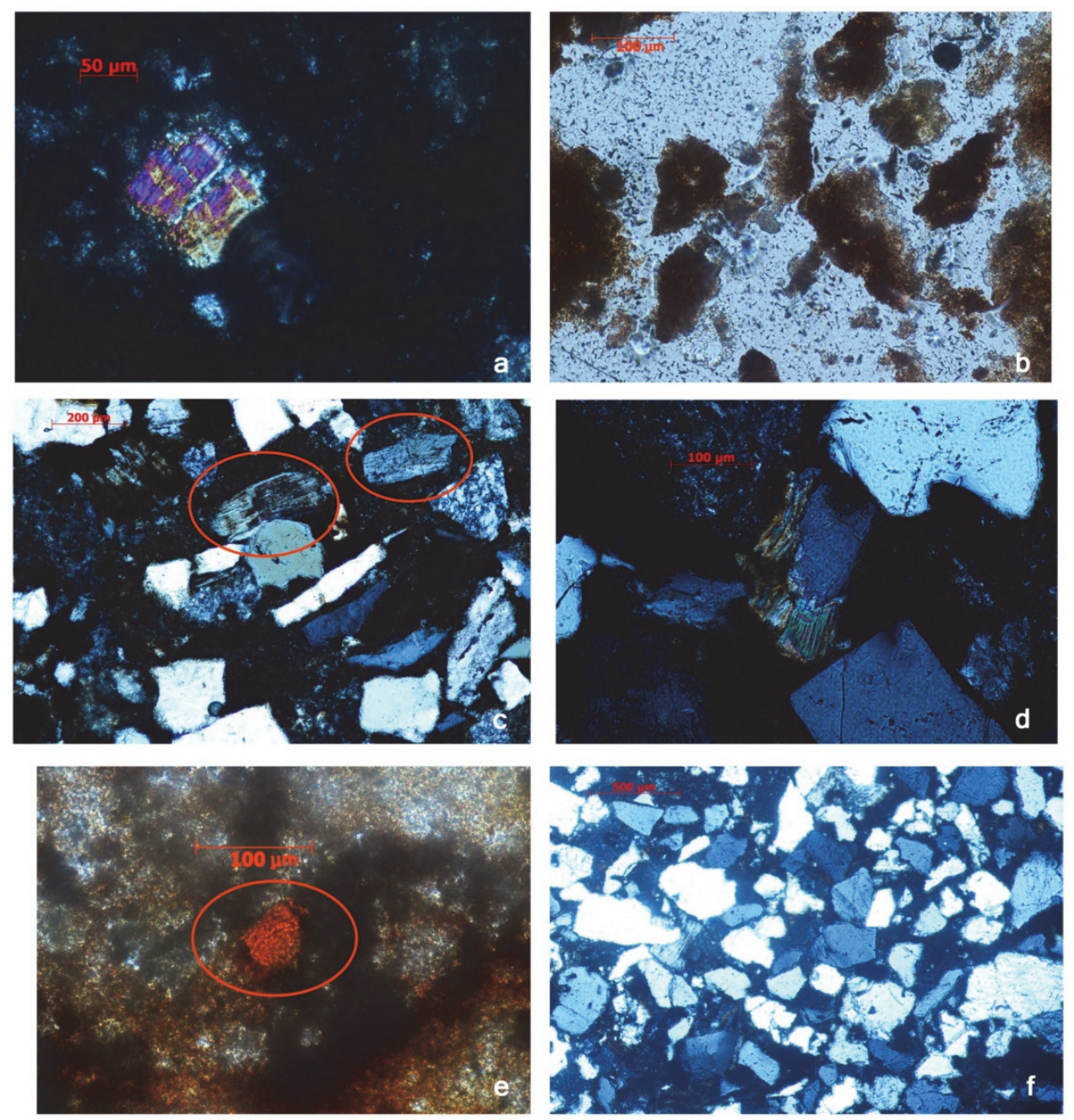

Figure 3. Microscopic characteristics of minerals in NW Junggar

a.Zircon, b.Iron infection, c.Tourmaline, d.Tourmaline, e.Rutile, f.Mineral grains 
The contribution of each mineral is indicated by the heavy mineral percentage accumulation curves of the samples (Fig. 4a). The content of zircon, hematite-limonite, magnetite, ilmenite and chromite are commonly high, while the content of tourmaline, ilmenite, garnet, monazite, pyrite, galena and allanite are comparatively low. In addition, rutile, anatase, apatite, epidote, pyroxene and hornblende represent a reasonable fraction of the content. The homogeneity of heavy mineral combinations of samples from various profiles and depths suggests that the sediments in NW Junggar maintained stable provenance during the sedimentation process (Kang et al., 2014).

Table 2. Heavy mineral grains statistics Milddle-Upper Triassic samles, NW Junggar (\%)

\begin{tabular}{|c|c|c|c|c|c|c|c|c|c|c|c|c|c|c|c|c|c|c|c|}
\hline Sample & Zircon & Tourmaline & Rutile & hematite-limonite & Magnetite & Ilmenite & Leucoxene & Anatase & Garnet & Chromite & Monazite & Pyrite & Galenite & Apatite & Allanite & Epidote & Pyroxene & Hornblende & Others \\
\hline $130523-4$ & 33.33 & 0 & 0 & 30.67 & 16.67 & 0 & 0 & 0 & 0 & 0 & 0 & 0.01 & 0 & 0 & 0 & 0 & 0 & 0 & 19.33 \\
\hline $130523-6$ & 0.59 & 0 & 0 & 0 & 0 & 2.21 & 1.02 & 0 & 0 & 0 & 0 & 0.01 & 0 & 0 & 0 & 0 & 0 & 0 & 96.17 \\
\hline $130523-8$ & 6.86 & 0 & 0 & 10.71 & 35 & 30 & 1.29 & 0 & 0 & 0 & 0 & 0.03 & 0 & 0 & 0 & 0 & 0 & 0 & 16.11 \\
\hline $130523-17$ & 18.6 & 0 & 0 & 0 & 0 & 0 & 0 & 0 & 0 & 0 & 0 & 0.03 & 0 & 0 & 0 & 0 & 0 & 0 & 82.37 \\
\hline $130523-21$ & 14.38 & 0 & 0 & 0 & 7.5 & 15 & 2.5 & 0 & 0 & 0 & 0 & 0.03 & 0 & 0 & 0 & 0 & 0 & 0 & 60.59 \\
\hline $130523-24$ & 9.3 & 0 & 0 & 0 & 0 & 0 & 0 & 0 & 0 & 0 & 0 & 0.03 & 0 & 0 & 0 & 0 & 0 & 0 & 90.67 \\
\hline $130602-1$ & 10.27 & 0 & 0 & 57.37 & 0 & 0.23 & 0 & 0 & 0 & 0 & 0 & 14.12 & 0.13 & 0 & 0 & 0 & 0 & 0 & 17.88 \\
\hline $130602-4$ & 35 & 0 & 0 & 0 & 0 & 1 & 0 & 0 & 0 & 0 & 0 & 10 & 0.5 & 0 & 0 & 0 & 0 & 0 & 53.5 \\
\hline $130602-5$ & 18.92 & 0 & 0 & 1.08 & 15.92 & 0 & 0 & 0.05 & 0 & 0 & 0 & 0.78 & 0 & 0 & 3.54 & 0 & 0 & 0 & 59.71 \\
\hline $130602-9$ & 2.19 & 0.03 & 0 & 28.71 & 27.06 & 12.82 & 0 & 0 & 0.03 & 0.03 & 0 & 0.19 & 0 & 0 & 0 & 0.14 & 0 & 1.58 & 27.22 \\
\hline $130603-1$ & 8 & 27.5 & 0 & 0 & 0 & 0 & 0 & 0 & 0 & 1.83 & 1.83 & 0.01 & 0 & 0.01 & 0 & 0 & 0 & 0 & 60.83 \\
\hline $130603-2$ & 11.3 & 9 & 0 & 0 & 0 & 0 & 0 & 0 & 0 & 0.9 & 0 & 0.55 & 0 & 0 & 0 & 0 & 0 & 0 & 78.25 \\
\hline $130603-7$ & 30.85 & 28.41 & 0 & 0 & 0.2 & 0 & 0 & 0.32 & 2.3 & 1.73 & 7.07 & 0 & 0 & 0.01 & 0 & 0 & 0 & 0 & 29.11 \\
\hline $130604-1$ & 0 & 0 & 0 & 3 & 0 & 0 & 0 & 0 & 10 & 0 & 0 & 0 & 0 & 0 & 0 & 0.01 & 0 & 0 & 86.99 \\
\hline $130604-5$ & 0.03 & 0 & 0 & 0 & 0 & 0 & 0 & 0 & 0.03 & 0 & 0 & 0 & 0 & 0 & 0 & 0 & 0 & 0 & 99.94 \\
\hline $130604-6$ & 19.6 & 0 & 0 & 0 & 0 & 40 & 0 & 0 & 0 & 32 & 0 & 1.6 & 0 & 0 & 0 & 0 & 0 & 0 & 6.8 \\
\hline $130604-7$ & 13.67 & 0 & 0 & 0 & 0 & 36.6 & 0 & 0 & 0 & 13.27 & 0 & 0.02 & 0 & 0 & 0 & 0 & 0 & 0 & 36.44 \\
\hline $130604-11$ & 3 & 0.1 & 0 & 67.65 & 4.6 & 0 & 0 & 0 & 0 & 0 & 0 & 1.65 & 5 & 0 & 0 & 0 & 0 & 0 & 18 \\
\hline $130605-4$ & 6.94 & 0.29 & 0.14 & 0 & 0.17 & 70.34 & 14.99 & 0 & 0 & 0 & 0 & 0.01 & 0 & 0 & 0 & 0 & 0 & 0 & 7.12 \\
\hline $130605-8$ & 10.79 & 0.95 & 0.17 & 3.53 & 0.09 & 69.31 & 5.86 & 0.08 & 0 & 0 & 0 & 0.24 & 0.01 & 0 & 0 & 0 & 0.38 & 0 & 8.59 \\
\hline
\end{tabular}

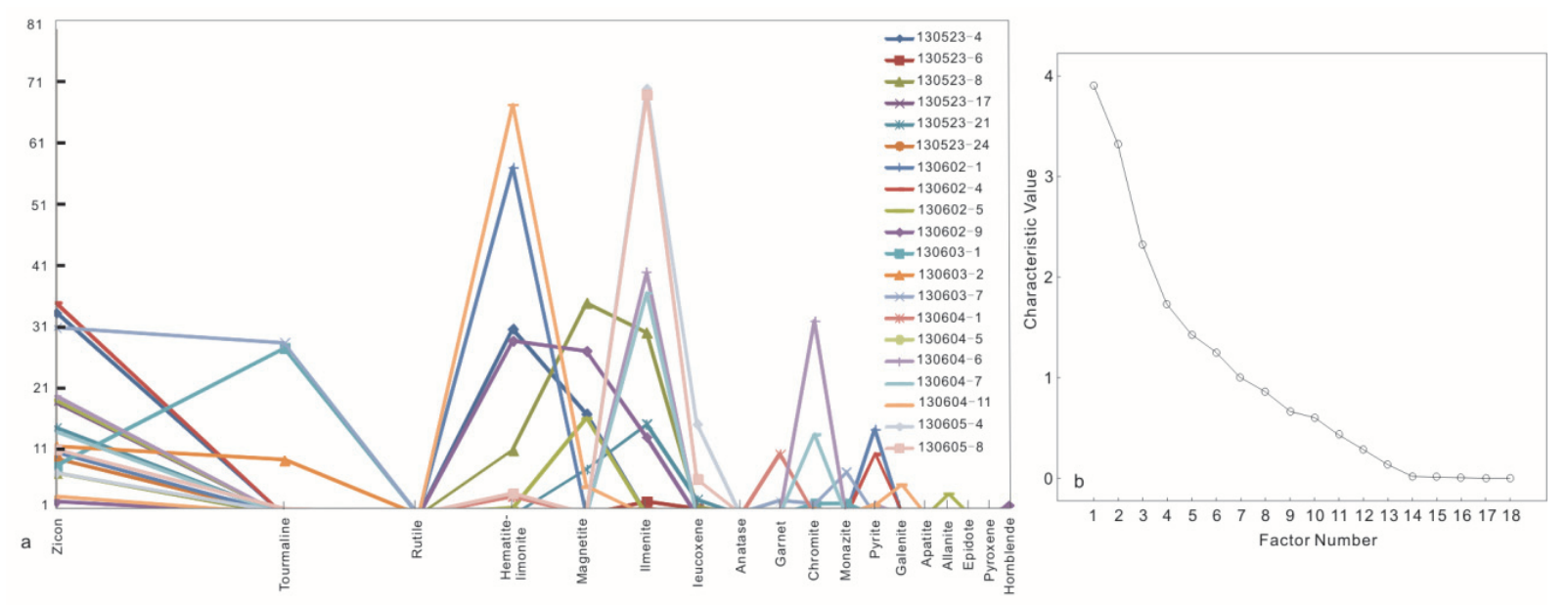

Figure 4a. Accumulation curves of heavy mineral percentage, NW Junggar Figuer 4b. Scree plot

Table 3. Factor matrix(after varimax rotation) of samples, NW Junggar

\begin{tabular}{lllllll}
\hline MineralLFactor & F1 & F2 & F3 & F4 & F5 & F6 \\
\hline Monazite & 0.97 & -0.07 & -0.03 & -0.05 & 0.03 & -0.02 \\
Apatite & 0.92 & -0.11 & -0.05 & -0.06 & -0.06 & -0.09 \\
Tourmaline & 0.91 & -0.11 & -0.06 & -0.08 & -0.08 & -0.09 \\
Anatase & 0.88 & 0.13 & -0.04 & -0.06 & 0.11 & 0.15 \\
Rutile & -0.01 & 0.98 & -0.07 & -0.02 & -0.03 & 0.01 \\
Ilmenite & -0.16 & 0.86 & 0.05 & -0.24 & 0.14 & -0.25 \\
Leucoxene & -0.09 & 0.84 & -0.07 & -0.08 & -0.09 & 0.00 \\
\hline
\end{tabular}




\begin{tabular}{lllllll}
\hline Pyroxene & 0.05 & 0.76 & -0.04 & 0.04 & 0.04 & 0.05 \\
Hornblende & -0.03 & -0.04 & 0.96 & 0.03 & -0.05 & -0.07 \\
Epidote & -0.03 & -0.05 & 0.96 & 0.03 & -0.09 & -0.07 \\
Magnetite & -0.16 & -0.09 & 0.68 & -0.03 & 0.13 & 0.43 \\
Hematite-limonite & -0.13 & -0.11 & 0.23 & 0.89 & 0.10 & 0.00 \\
Galenite & -0.06 & -0.05 & -0.07 & 0.79 & -0.09 & -0.02 \\
Pyrite & -0.12 & -0.16 & -0.17 & 0.50 & 0.45 & -0.09 \\
Zircon & 0.34 & -0.13 & -0.22 & -0.13 & 0.72 & 0.12 \\
Garnet & 0.12 & -0.17 & -0.13 & -0.11 & -0.65 & -0.02 \\
Allanite & -0.08 & -0.11 & -0.03 & -0.21 & 0.21 & 0.76 \\
Chromite & -0.11 & -0.10 & -0.07 & -0.36 & 0.40 & -0.63 \\
Variance contribution & 21.12 & 17.51 & 13.08 & 10.89 & 8.07 & 7.23 \\
Accumulated variance percentage \% & 20.12 & 37.64 & 51.44 & 62.32 & 70.40 & 77.62 \\
\hline
\end{tabular}

\subsection{Component Analysis}

Component analysis (also called "main component analysis") is a multivariate statistical method involving the use of a few representative factors to describe the primary information extracted from a number of variables while analyzing a rich supply of data. Applying a R-type analysis to study the above 18 heavy minerals in the selected 20 rock samples, the accumulated variance percentage of the first 6 factors are found to be over $77.62 \%$. According to the scree plot, the steep slope of the curve begins to become flat from the $6^{\text {th }}$ factor point, and the curve is nearly flattened until the $14^{\text {th }}$ factor point (Fig. 4b). It is interpreted that only the first 6 factors have strong variability; however, the last 12 factors account for a small part of the variability, which may have little impact. Consequently, the first 6 factors are extracted as the main factors; subsequently, the Kaiser standardized varimax method is used to perform varimax rotation to gain the factor loading matrix (Table 3).

A portion of the interpreted information $(20.12 \%)$ of the first main factor is the main geological element of the heavy mineral distribution in the study area. F1 represents the combination of monazite-apatite-tourmaline-antase, and $17.52 \%$ of the interpreted information of F2 represents the rutile-ilmenite-leucoxene-pyroxene combination. The first two main factors contain the unstable mineral pyroxene and the unstable minerals apatite, monazite, ilmenite and leucoxene; the rest of the minerals are ultra-stable minerals. A portion of the interpreted information $(13.80 \%)$ of F3 represents the amphibole-epidote-magnetite combination. A portion of the interpreted information (10.88\%) of F4 represents the hematite-limonite-galenite-pyrite combination. In these two combinations, hornblende, galenite, epidote, and pyrite belong to medium-stable to unstable minerals and magnetite, hematite-limonite belong to stable minerals. The interpreted information of F5 and F6 are $8.08 \%$ and $7.22 \%$, respectively, corresponding to the zircon-garnet and allanite-chromite combinations. Among these minerals, zircon is an ultra-stable mineral, chromite is a stable mineral, and garnet and allanite are medium-stable minerals.

Because of the low contribution ratio, the data of F5 and F6 are not suitable for graphing. According to the graph comparison of the other F1 to F4 factors, it is shown that two combinations are selected in the F1-F2 correlation graph: rutile-ilmenite-leucoxene-pyroxene and anatase-monazite-tourmaline-apatite ( Fig. 5a). The combinations of hornblende-epidote-magnetite and anatase-monazite-tourmaline-apatite-zircon-ilmenite are selected in the F1-F3 correlation graph (Fig. 5b. The hematite-limonite-galenite-pyrite and hornblende-epidote-magnetite combinations are selected in the F3-F4 correlation graph (Fig. 5c). The hornblende-epidote-magnetite and rutile-ilmenite-leucoxene-pyroxene combinations are selected in F2-F3 (Fig. 5d). The heavy minerals, which are selected together, indicate that they are closely associated minerals. These combinations provide evidence of the predicted source rock. 

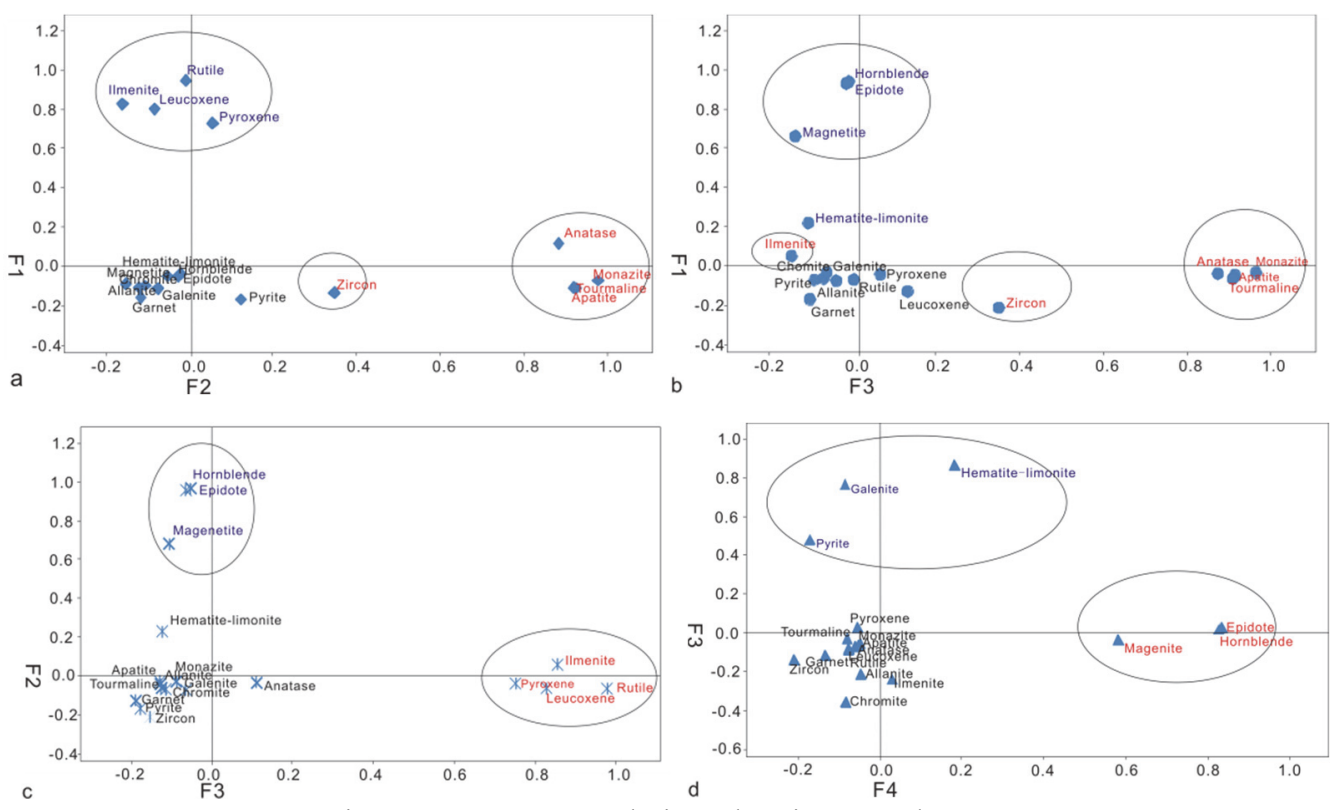

Figure 5. Factor correlation plots in rotated space

F1-F2; b. F1-F3; c.F3-F4; d.F2-F3

\subsection{Correlation Analysis}

Heavy mineral combinations from samples of various provenances have dissimilar characteristics. Correlation analysis of the multivariate statistical theory (also named similarity analysis) is used to search the correlation among the heavy minerals (Table 4)(Du et al., 2011), and to further determine the source rock types on basis of the combinations. According to the correlation analysis of the heavy minerals, four combinations exist in the study area.

According to the correlation analyze of heavy minerals, the result indicates that four combinations are exist in study area.

Zircon-tourmaline-anatase-monazite-apatite combination: The correlation coefficient of tourmaline and monazite is within 0.8-0.97, the same as tourmaline and apatite, anatase and monazite, and monazite and apatite, which exhibit the highest positive relationships. The correlation coefficient of 0.64 between tourmaline and monazite is higher, while the correlation coefficient of 0.5 between zircon and anatase and zircon and monazite exhibits the lowest positive correlation.

Rutile-ilmenite-leucoxene-pyroxene: In addition to the low positive correlation between ilmentite and pyroxene, with the correlation coefficient of 0.56 , the other coefficients have a high positive correlation, within the range of 0.7 to 0.85 .

Galenite-hematite-limonite-pyrite: The correlation coefficient between galenite and hematite-limonite is 0.68 , exhibiting a relatively high positive correlation. The correlation coefficient between hematite-limonite and pyrite is below 0.5 , exhibiting a low positive correlation.

Magnetite-epidote-hornblende: The correlation coefficient is approximately 0.5 , which exhibits a relatively low positive correlation.

The negative relationships among the heavy minerals are relatively low, within the range of -0.2 to 0.01 . Therefore, the 4 combinations mentioned above probably belong to a major provenance of the environment but come from different source rocks, and there is connection among these source rocks.

\section{Discussion of the Source Rock and Its Provenance}

In previous research, the original data of Junggar provenance came from oilfield exploration information and well-logs, and the paleo-current was analyzed on the basis of the sedimentary facies distribution. However, the sediment source evidence of the NW Junggar Triassic is deficient, and the examples of the provenance direction prediction are rare. 
Through the research of the 20 clastic rock samples on the NW Junggar, two zircon types were found, which came from different source rocks. The yellowish-pink automorphic to hypautomorphic zircon is has magmatite zircon characteristics, with poor grinding and medium separation, leading to the probable prediction of the nearby provenance. However, a few rose-colored sub-rounded zircons are also found in the sedimentary zircon characteristics, with better grinding and sorting, resulting in the prediction of a certain distance of transportation. The high-temperature magmatic tourmaline is mostly brown to black brown, with an automorphic to hypautomorphic columnar shape and are probably coronite coming from granite. In addition, there are a few sedimentary tourmalines and rutiles, which are sub-rounded to rounded grains, and intermediate acidic to acidic magmatite that is deposit associated with iron and copper ore; these results are interpreted as being due to the accumulated iron ore, such as ilmenite, hematite-limonite, magnetite, and so on. A certain content of hornblende, mica debris, apatite, and monazite also provides proof of the probable presence of intermediate-acid magmatite source rocks. A few metamorphic minerals, such as garnet and their clastics, indicate that the content may be from metamorphic rocks (Xie et al., 2007).

Different heavy mineral combinations represent different provenance or types of source rocks (Li et al., 2010). Applying the three research methods of heavy minerals described above, four combination types of heavy minerals are developed on the NW Junggar: zircon-tourmaline-anatase-monazite-apatite, rutile-ilmenite-leucoxene-pyroxene, galenite-hematite-limonite-pyrite, and magnetite-epidote-hornblende. The first two combinations mainly consist of stable minerals, while the unstable mineral content of the other two combinations are relatively higher. According to the separation, grinding and heavy mineral stableness of grains, it is concluded that the sediments of the study area are probably from the composition of near and distal deposits. However, regardless of the heavy or light minerals, most grains are angular to subangular and subangular to subround in general (Fig. 3f), and the percentage of subround to round grain is below $10 \%$. Therefore, the sediments are mostly near-provenance deposits.

With the above techniques, it is concluded that the source rocks of the Middle-Upper Triassic on the NW Junggar are combinations of intermediate-acidic magmatite, sedimentary rocks and metamorphic rocks; also, the intermediate-acidic magmatite is considered to be the main source rock. The provenance is the Qier-Alahalat Mountain area, which belongs to the Front Zaire Mountain, is located northwest of the Junggar. The Tailegula Formation is widely developed in this area. The deposits of the Tailegula Formation are composed of large sets of grey to greyish-black thin tuff, interbeded with andesite and andesitic porphyrite, which is also likely to a source of intermediate-acidic magmatite clastics. The siltstones and fine-grain sandstones are interbeded with each other, forming sedimentary source rocks. In addition, the two sets of granite and granodiorite near the study area can also provide clastics.

Table 4. Heavy mineral correlation coefficient of Milddle-Upper Triassic, NW Junggar

\begin{tabular}{|c|c|c|c|c|c|c|c|c|c|c|c|c|c|c|c|c|c|c|}
\hline Mineral & Zircon & Tournaline & Rutile & $\begin{array}{l}\text { Hematite- } \\
\text { Limonite }\end{array}$ & Magnetite & Ilmenite & Leucoxene & Anatase & Gamet & Chromite & Monazite & Pyrite & Galenite & Apatite & Allanite & Epidote & Pyroxene & Homblende \\
\hline Zircon & 1 & 0.21 & -0.12 & -0.14 & -0.04 & -0.11 & -0.16 & 0.4 & -0.19 & 0.17 & 0.37 & 0.25 & -0.17 & 0.22 & 0.14 & -0.25 & -0.04 & -0.23 \\
\hline Tourmaline & 0.21 & 1 & -0.1 & -0.2 & -0.21 & -0.22 & -0.13 & 0.64 & 0.07 & -0.05 & 0.84 & -0.15 & -0.1 & 0.97 & -0.09 & -0.1 & -0.06 & -0.09 \\
\hline Rutile & -0.12 & -0.1 & 1 & -0.14 & -0.17 & 0.82 & 0.84 & 0.1 & -0.09 & -0.11 & -0.09 & -0.12 & -0.08 & -0.11 & -0.08 & -0.08 & 0.76 & -0.08 \\
\hline $\begin{array}{l}\text { Hematite- } \\
\text { Limonite }\end{array}$ & -0.14 & -0.2 & -0.14 & 1 & 0.23 & -0.21 & -0.17 & -0.15 & -0.11 & -0.17 & -0.15 & 0.44 & 0.68 & -0.17 & -0.11 & 0.21 & -0.08 & 0.22 \\
\hline Magnetite & -0.04 & -0.21 & -0.17 & 0.23 & 1 & 0.01 & -0.1 & -0.11 & -0.15 & -0.18 & -0.15 & -0.18 & -0.03 & -0.18 & 0.24 & 0.49 & -0.12 & 0.5 \\
\hline Ilmenite & -0.11 & -0.22 & 0.82 & -0.21 & 0.01 & 1 & 0.77 & -0.02 & -0.17 & 0.32 & -0.17 & -0.19 & -0.16 & -0.21 & -0.14 & -0.02 & 0.56 & -0.01 \\
\hline Leucoxene & -0.16 & -0.13 & 0.84 & -0.17 & -0.1 & 0.77 & 1 & -0.02 & -0.1 & -0.13 & -0.11 & -0.14 & -0.1 & -0.12 & -0.09 & -0.09 & 0.31 & -0.09 \\
\hline Anatase & 0.4 & 0.64 & 0.1 & -0.15 & -0.11 & -0.02 & -0.02 & 1 & 0.15 & -0.05 & 0.92 & -0.12 & -0.08 & 0.64 & 0.09 & -0.08 & 0.19 & -0.07 \\
\hline Gamet & -0.19 & 0.07 & -0.09 & -0.11 & -0.15 & -0.17 & -0.1 & 0.15 & 1 & -0.08 & 0.15 & -0.11 & -0.07 & 0.08 & -0.06 & 0.01 & -0.06 & -0.06 \\
\hline Chromite & 0.17 & -0.05 & -0.11 & -0.17 & -0.18 & 0.32 & -0.13 & -0.05 & -0.08 & 1 & -0.03 & -0.04 & -0.09 & -0.03 & -0.08 & -0.08 & -0.08 & -0.08 \\
\hline Monazite & 0.37 & 0.84 & -0.09 & -0.15 & -0.15 & -0.17 & -0.11 & 0.92 & 0.15 & -0.03 & 1 & -0.11 & -0.07 & 0.85 & -0.06 & -0.07 & -0.06 & -0.06 \\
\hline Pyrite & 0.25 & -0.15 & -0.12 & 0.44 & -0.18 & -0.19 & -0.14 & -0.12 & -0.11 & -0.04 & -0.11 & 1 & 0.09 & -0.13 & -0.04 & -0.09 & -0.08 & -0.08 \\
\hline Galenite & -0.17 & -0.1 & -0.08 & 0.68 & -0.03 & -0.16 & -0.1 & -0.08 & -0.07 & -0.09 & -0.07 & 0.09 & 1 & -0.09 & -0.06 & -0.06 & -0.06 & -0.06 \\
\hline Apatite & 0.22 & 0.97 & -0.11 & -0.17 & -0.18 & -0.21 & -0.12 & 0.64 & 0.08 & -0.03 & 0.85 & -0.13 & -0.09 & 1 & -0.08 & -0.08 & -0.08 & -0.08 \\
\hline Allenite & 0.14 & -0.09 & -0.08 & -0.11 & 0.24 & -0.14 & -0.09 & 0.09 & -0.06 & -0.08 & -0.06 & -0.04 & -0.06 & -0.08 & 1 & -0.06 & -0.05 & -0.05 \\
\hline Epidote & -0.25 & -0.1 & -0.08 & 0.21 & 0.49 & -0.02 & -0.09 & -0.08 & 0.01 & -0.08 & -0.07 & -0.09 & -0.06 & -0.08 & -0.06 & 1 & -0.06 & 1 \\
\hline Pyroxene & -0.04 & -0.06 & 0.76 & -0.08 & -0.12 & 0.56 & 0.31 & 0.19 & -0.06 & -0.08 & -0.06 & -0.08 & -0.06 & -0.08 & -0.05 & -0.06 & 1 & -0.05 \\
\hline Homblende & -0.23 & -0.09 & -0.08 & 0.22 & 0.5 & -0.01 & -0.09 & -0.07 & -0.06 & -0.08 & -0.06 & -0.08 & -0.06 & -0.08 & -0.05 & 1 & -0.05 & 1 \\
\hline
\end{tabular}

During provenance analysis, the evidence of the tectonic background and the activities support each other. The Junggar Basin Triassic is a depressed basin that has experienced long periods of low-speed depression. The southwest to northeast direction thrust faults are developed at the northwest margin, causing the mixture of 
clastics. Thus, the provenance pushes forward, which may result in several different source contents. In particular, because of the regional dynamic metamorphism effect, the rocks from the provenance were under the process of chloritization and epidotization to different degrees. However, there are limitations for the use of the heavy mineral combination method to predict provenance; for example, hydrodynamic forces may cause heavy mineral property changes and so on. Therefore, for the application of clastic heavy minerals in provenance analysis, note that combining and verifying several methods is effective to well-predict the source rock and provenance.

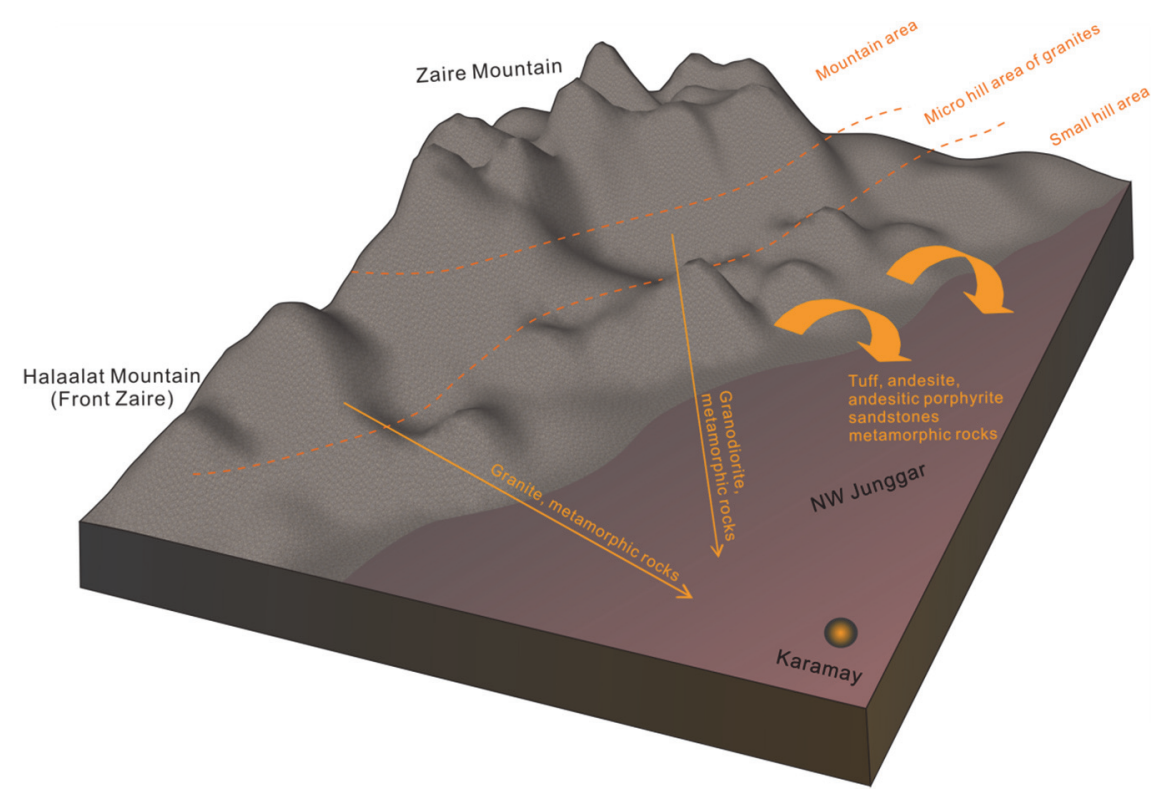

Figure 6. Provonance distribution of NW Junggar

\section{Conclusions}

Combining the methods of mineral combination identification, heavy mineral percentage distribution, SPSS statistic \& component analysis and correlation analysis, the heavy mineral characteristics at the NW Junggar were described in detail. The source rock combinations and their provenance significance were discussed, and 4 findings are summarized as follows:

1) Eighteen heavy minerals are identified in the Middle to Upper Triassic samples in the NW Junggar, with most of the grains being angular to subangular and subangular to subround; the contents of zircon, tourmaline and iron ore was found to be commonly high. Among these minerals, there are two zircon types: a yellowish-pink type and a rose-colored type. Brown tourmaline is contained in samples, and a certain content of hornblende, mica debris, apatite, monazite and a few metamorphic minerals and alteration mineral clastics are also included, with the grains exhibiting partial limonitization.

2) Four heavy mineral combinations are classified in the NW Junggar: zircon-tourmaline-monazite-apatite-anatase, rutile-ilmenite-leucoxene-apatite-galenite, hematite-limonite-pyrite and magnetite-epidote-hornblende. The first two combinations are mainly composed of stable minerals, while the unstable mineral content of the latter two are relatively higher. According to the separation, grinding and heavy mineral stableness of the grains, it is concluded that most are probably from the near-provenance, although the sediments compose the near and distal deposits.

3) There is large amount of columnar zircon, worm-shaped tourmaline of an automorphic to hemiautomorphic form exhibiting characteristics of magmatic origin. Due to the content of rutile, monazite, apatite, pyroxene, hornblende and abundant iron, especially magnetite and ilmenite, it is predicted that intermediate-acid magmatite is included in the source rocks. Subrounded to rounded sedimentary zircon and tourmaline indicate that sedimentary rocks are also included. Some symbol minerals of metamorphic rocks, such as garnet, allanite, epidote, and so on also suggest that a few metamorphic rocks are included.

4) The provenance of the study area is the Qier-Halaalat Mountain area located northwest-north of the study area, belonging to the Front Zaire Mountain. The source rocks are composed of intermediate-acid magmatite, 
sedimentary rocks and metamorphic rocks from the Tailegula Formation, and are mainly intermediate-acid magmatite. The intermediate-acid magmatite probably consists of tuff, andesite, andesitic porphyrite and granite and granodiorite intrusive bodies. Siltstones and fine-grain sandstones are the main sedimentary source rocks. The metamorphic content may be caused by partial chloritization and epidotization from the regional dynamic metamorphism.

\section{Acknowledgement}

I am grateful to the laboratory of Langfang Geology and Mineral Resources Survey for the processing and identification of heavy minerals! Also I would like to express my thanks to Researcher Song Tian-rui for his beneficial suggestions!

\section{References}

Cao, L. C., Jiang, T., \& Wang, Z. F., et al. (2013). Characteristics of heavy minerals and their implications for Neogene provenances evolution in Qiongdongnan basin[J]. Journal of Central South University (Science and Technology), (05), 1971-1981.

Carroll, A. R., Graham, S. A., \& Smith, M. E. (2010). Walled sedimentary basins of China[J]. Basin Research, 22(01), 11-32.

Chen, B., \& Jahn, B. (2004). Genesis of post-collisional granitoids and basement nature of the Junggar Terrane, NW China: Nd-Sr isotope and trace element evidence[J]. Journal of Asian Earth Sciences, 23(5), 691-703.

Chen, J., Han, B., \& Ji, J., et al. (2010). Zircon U-Pb ages and tectonic implications of Paleozoic plutons in northern West Junggar, North Xinjiang, China[J]. Lithos, 115(1-4), 137-152.

Choulet, F., Chen, Y., Cogné, J., et al. (2013). First Triassic Palaeomagnetic Constraints from Junggar (NW China) and Their Implications for the Mesozoic Tectonics in Central Asia[J]. Journal of Asian Earth Sciences, 2, 1-24.

Du, Q., \& Jia, L. Y. (2001). SPSS statistical analysis from entry to the master [M]. Beijing: Posts and Telecom Press, 234-288.

Gao, R., Xiao, L., \& Wang, G. C., et al. (2013). Paleozoic magmatism and tectonic setting in west Junggar.[J]. Acta Petrologica Sinica, 29(10), 3413-3434.

Geng, H., Sun, M., \& Yuan, C., et al. (2009). Geochemical, Sr-Nd and zircon U-Pb-Hf isotopic studies of Late Carboniferous magmatism in the West Junggar, Xinjiang: Implications for ridge subduction?[J]. Chemical Geology, 266(3-4), 364-389.

Kang, C. G., Li, C. A., \& Zhang, Y. F., et al. (2014). Heavy mineral characteristics of the Yichang gracel layers and provenance Tracing[J]. Acta Geologica Sinica, 88(02), 254-262.

Li, W. (2007). The mechanic and tectonic evolution of Mesozoic basins in northwestern Junggar orogenic belt[D]. Chinese Academy of Geological Sciences, 20-36.

Li, Z. X., Chang, X. C., \& Zhao, X. L. (2010). Lithofacies-paleogeography[M]. Beijing: Geological Publishing House.

Lin, T., Wang, D. L., \& Wang, L., et al. (2013). The provenance feature of Jurassic Qugu Formation and its effect on reservoir development in the southern margin of Junggar basin[J]. Geology in China, 40(3), 909-918.

Svendsen, J. B., \& Hartley, N. R. (2002). Synthetic heavy mineral stratigraphy: applications and limitations[J]. Marine and Petroleum Geology, 19(4), 389-405.

Xiao, Y., Zhang, H., \& Shi, J., et al. (2011). Late Paleozoic Magmatic Record of East Junggar, NW China and its Significance: Implication from Zircon U-Pb Dating and Hf Isotope[J]. Gondwana Research, 20(02), 532-542.

Xie, J., \& Ding, Z. (2007). Compositions of heavy minerals in Northeastern China sandlands and provenance analysis[J]. Science in China Series D: Earth Sciences, 50(11), 1715-1723.

Xu, H., Liu, Y. Q., \& Kuang, H. W., et al. (2013). Sedimentary provenance and basin evolution of Daqingshan Formation, Houcheng Formation and Tuchengzi Formation in Yinshan-Yanshan area[J]. Geological Bulletin of China, 32(2-3), 502-524.

Yalcin, M. G. (2008). Heavy mineral distribution as related to environmental conditions for modern beach sediments from the Susanoglu (Atakent, Mersin, Turkey)[J]. Environmental Geology, 58(1), 119-129. 
Yang, F., Chen, G., \& Zhang, H. R., et al. (2013). LA-ICP-MSU-Pb dating of detrital zircon from the Mesozoic sandstone core-samples in well DB1 of the northeast Junggar basin[J]. Journal of Lanzhou Univrsity(Natural Sciences), 49(3), 313-319.

Yang, R. C., Li, J. B., \& Fan, A. P., et al. Research progress and development tendency of provenance analysis on terrigenous sedimentary rocks [J]. Acta Sedimentologica Sinica, 31(01), 99-107.

Yang, S., Wang, Z., Guo, Y., et al. (2009). Heavy mineral compositions of the Changjiang (Yangtze River) sediments and their provenance-tracing implication[J]. Journal of Asian Earth Sciences, 35(1), 56-65.

Zhang, Y. P. (2014). The characteristics of sedimentary provenance and facies of second member of Xiazijie Formation in Bai-21 well block, Junggar Basin[J]. Xinjiang Petroleum Geology, 35(2), 153-157.

Zhao, X. S., Gao, Z. Y., \& Feng, J. R., et al. (2014). Triassic-Neogene heavy minerals' assemblages characteristics and basin-orogen tectonic evolution relationship in the Kuqa foreland basin[J]. Acta Sedimentologica Sinica, 32(01), 68-77.

Zheng, Y., \& Kong, P. (2013). Provenance and origin of the Late Cenozoic Dayi conglomerates in the western margin of the Sichuan Basin: New insightsfrom heavy mineral and spore-pollen assemblages[J]. Acta Petrologica Sinica, 29(08), 2949-2958.

\section{Copyrights}

Copyright for this article is retained by the author(s), with first publication rights granted to the journal.

This is an open-access article distributed under the terms and conditions of the Creative Commons Attribution license (http://creativecommons.org/licenses/by/4.0/). 